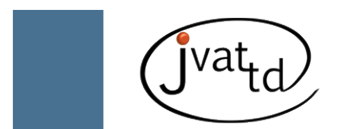

\title{
Bothrops jararacussu venom-induced neuromuscular blockade inhibited by Casearia gossypiosperma Briquet hydroalcoholic extract
}

\author{
Camargo TM (1), Nazato VS (1), Silva MG (1), Cogo JC (2), Groppo FC (3), Oshima-Franco Y (1)
}

(1) School of Pharmacy, University of Sorocaba, UNISO, Sorocaba, São Paulo State, Brazil; (2) Vale do Paraíba University, UNIVAP, São José dos Campos, São Paulo State, Brazil; (3) Piracicaba Dental School, State University of Campinas, UNICAMP, Piracicaba, São Paulo State, Brazil.

\begin{abstract}
The hydroalcoholic extract of Casearia gossypiosperma Briquet (Flacourtiaceae) was standardized for the first time through quality control procedures including pharmacognostic methods, fingerprint chromatograms, defined amounts of marker substances and physicochemical characteristics. The pharmacological activity of C. gossypiosperma $(\mathrm{Cg})$ hydroalcoholic extract was assayed by a traditional in vitro test, which involved irreversible neuromuscular blockade induced by Bothrops jararacussu (Bjssu) venom $(60 \mu \mathrm{g} / \mathrm{mL})$ in mouse phrenic nerve-diaphragm preparations. Bjssu venom blocked muscle activity for 26 $( \pm 2.0)$ minutes $(n=6)$. Cg extract $(0.1 \mathrm{mg} / \mathrm{mL})$ induced changes on the baseline muscle activity without impairing the muscle function and inhibited $87.6 \%( \pm 1.8)(n=6)$ of the Bjssu venom-induced blockade. Both flavonoids $(0.624 \mathrm{~g} \%)$ and polyphenols $(4.63 \mathrm{~g} \%)$ from the extract were spectrophotometrically quantified. Therefore, the present study confirms the antibothropic activity of $\mathrm{Cg}$ extract, supporting the ethnomedical use of Casearia sp. in the treatment of snakebite victims.
\end{abstract}

Key words: antibothropic extract, Bothrops jararacussu, Casearia gossypiosperma Briquet, snake venoms.

\section{INTRODUCTION}

The genus Casearia is one of the 86 members of the family Flacourtiaceae. It includes around 180 species that occur throughout the tropics and are widespread in the Americas, Africa, Asia, Malaysia, Australia and islands of the Pacific Ocean (1). At least 16 Casearia species have shown biological activity such as cytotoxic [C. arborea; C. grayi; C. grewiifolia; C. lucida; C. multinervosa; C. nigrescens; C. obliqua (28)]; antifungal [C. decandra (9)]; antidiabetic [C. esculenta (10)]; immunomodulatory [C. guianensis (11)]; antifertility [C. ilicifolia (12)]; antiophidian [C. mariquitensis (13)]; antitumor [C. membranacea (14)]; genotoxic [C. tomentosa (15)]; and antioxidant actions [C. velutina (16)]. The most studied among them is Casearia sylvestris Sw. that has shown several biological activities, including antitumor, antiulcer, analgesic, anti-inflammatory, cytotoxic, antifungal, anticancer, anti-snake and bee venom $\mathrm{PLA}_{2}$, genotoxic, trypanocidal, enzyme inhibitory, antihyperlipidemic and antibothropic properties (17-27). The latter have been used as antivenom in folk medicine by isolated Brazilian communities (22).

Geographical isolation helps reinforce the need of traditional and local medical practices, selecting natural resources for the treatment of many diseases, including snakebites (28). In addition, recognizing the potential of a medicinal plant could also contribute to preserve it.

In this study, Casearia gossypiosperma Briquet, a native tree from Brazil and popularly known as "pau-de-espeto", was pharmacognostically and 
pharmacologically assessed for the first time. In vivo myotoxic effects and in vitro irreversible neuromuscular blockade effects of crude venom from the snake Bothrops jararacussu are well known pharmacological methods used to study drugs showing antivenom properties (29, 30 ). Thus, the aim of the present study was to verify the capability of Casearia gossypiosperma hydroalcoholic extract to neutralize the neuromuscular blockade induced by Bothrops jararacussu venom.

\section{MATERIALS AND METHODS}

\section{Plant Material and Extraction}

Leaves from an adult C. gossypiosperma Briquet (Cg) tree were collected from the herbarium at the Higher School of Agriculture Luiz de Queiroz (ESALQ) of the University of São Paulo, Piracicaba, São Paulo, Brazil, in January 2006; the species was previously identified in 1988 (protocol IAC 38115). Cg leaves were dried at $35^{\circ} \mathrm{C}$ to $40^{\circ} \mathrm{C}$ for 24 hours. The dried leaves were then powdered, ground in a mill, macerated ( $200 \mathrm{~g}$, during five days) in $2 \mathrm{~L}$ of $70 \%$ ethanol and the suspension was percolated (under protection against light) at 20 drops/minute, resulting in a $10 \%(\mathrm{~m} / \mathrm{v})$ hydroalcoholic extract.

\section{Quality Control Assays of the Medicinal Plants}

\section{Ash and humidity tests}

To observe elementary physical and chemical characteristics, $\mathrm{Cg}$ powder was subjected to ash and humidity tests (31). Briefly, $100 \mathrm{~g}$ of the specimen powder were placed in six calibrated melting pots, which were warmed until total carbonization of the powders. The melting pots were kept at $650^{\circ} \mathrm{C}$ and the ashes were then weighed. Results are expressed as grams of ashes/100 $\mathrm{g}$ of sample. The humidity test was performed by placing $1 \mathrm{~g}$ of specimen powder in six calibrated porcelain capsules, which were heated at $105^{\circ} \mathrm{C}$ during four hours and then weighed.

\section{Thin Layer Chromatography (TLC)}

Aliquots of the hydroalcoholic extract were spottedonthin-layersilicagel plates $(0.3$-mmthick, Merck, Germany) with appropriate standards (32). The solvent system consisted of solvent A (ethyl acetate:formic acid:water, 90:10:10, v/v) and solvent B (acetone:chloroform:formic acid, 10:75:8, v/v). The phytochemical groups used as standards (1\% methanol m/v, PA solution, Sigma Chemical Co., USA) were apigenin, quercetin and rutin. Methanol extract from Casearia sylvestris Sw. was compared to Cg hydroalcoholic extract (27). The separated spots were visualized (under UV light at $360 \mathrm{~nm}$ ) with NP/PEG, as follows: $5 \%(\mathrm{v} / \mathrm{v})$ ethanolic NP (diphenylboric acid 2-aminoethyl ester, Sigma Chemical Co., USA) followed by 5\% (v/v) ethanolic PEG 4000 (polyethylene glycol 4000, Synth Chemical Co., Brazil). The retention factor (Rf) of each standard was compared with the spots exhibited by the tested extracts.

\section{Determination of Flavonoids and Polyphenols \\ Flavonoid content}

The flavonoid content was determined in $\mathrm{Cg}$ hydroalcoholic extract as described elsewhere (33). The method is based on the UV absorption of $\mathrm{AlCl}_{3}$-flavonoid complexes, expressed as total quercetin content. Briefly, $80 \%$ methanol $(50 \mathrm{~mL})$ was added to $10 \mathrm{~mL}$ extract, and $5 \mathrm{~mL}$ solution were transferred to volumetric flasks and diluted again with $80 \%$ methanol $(50 \mathrm{~mL})$. Four aliquots $(2 \mathrm{~mL})$ of solution were mixed with $2 \mathrm{~mL}$ of $5 \%$ anhydrous aluminum chloride solution $\left(\mathrm{AlCl}_{3}\right.$; complexing agent) and adjusted to $10 \mathrm{~mL}$ with $80 \%$ methanol. After 15 minutes, the absorbance of samples was read at $420 \mathrm{~nm}$, considering a blank sample containing $80 \%$ methanol (8 $\mathrm{mL})$ and $5 \% \mathrm{AlCl}_{3}(2 \mathrm{~mL})$. The percentage of flavonoids (\%) was calculated from a standard curve of quercetin $(0,4,8,12$, and $16 \mu \mathrm{g} / \mathrm{mL})$ prepared with methanol.

\section{Polyphenol content}

The polyphenol content in $\mathrm{Cg}$ hydroalcoholic extract was determined as previously described (34). Briefly, $5 \mathrm{~mL}$ extract was poured into a volumetric flask and distilled water was added to $250 \mathrm{~mL}$; then, a $1 \mathrm{~mL}$ aliquot was transferred to another volumetric flask and distilled water added to $25 \mathrm{~mL}$ (final solution). Aliquots (1 $\mathrm{mL}$ ) of the final solution received $1 \mathrm{~mL}$ of phosphomolybdotungstic reagent and the final volume $(10 \mathrm{~mL})$ was adjusted with $15 \%$ sodium carbonate solution. After 30 minutes, the absorbance of samples was read at $720 \mathrm{~nm}$, considering a blank sample containing 15\% 
sodium carbonate solution. The percentage of polyphenols (\%) was determined from a standard curve $(5,10,15,20,25,30,35$, and $40 \mu \mathrm{g} / \mathrm{mL})$ of pyrogallol (Sigma Chemical Co., USA).

\section{Pharmacological Tests}

\section{Animals}

Male Swiss white mice (26-32 g) were supplied by Anilab Animais de Laboratório (Brazil). Animals were housed at $25 \pm 3^{\circ} \mathrm{C}$ under a 12-hour light-dark cycle with access to food and water ad libitum. This study was approved (protocol number A009/2006 CEP) by the Research Ethics Committee of the Vale do Paraiba University (UNIVAP) and all experiments were performed according to the guidelines of the Brazilian Society of Laboratory Animal Science (SBCAL/ CEUA).

\section{Bothrops venom}

Crude venom was obtained from adult Bothrops jararacussu (Bjssu) snakes (Serpentarium of the Nature Study Center, UNIVAP) and certified by Prof. Dr. Jose Carlos Cogo, Vale do Paraiba University (UNIVAP), São José dos Campos, SP, Brazil.

\section{Mouse phrenic nerve-diaphragm muscle (PND) preparation}

PND was obtained from mice anesthetized with halothane and sacrificed by exsanguinations (35). The diaphragm was removed and mounted under a tension of $5 \mathrm{~g}$ in a $5 \mathrm{~mL}$ organ bath containing continuously aerated Tyrode solution (control) with the following composition: 137 $\mathrm{mM} \mathrm{NaCl}, 2.7 \mathrm{mM} \mathrm{KCl}, 1.8 \mathrm{mM} \mathrm{CaCl}_{2}, 0.49 \mathrm{mM}$ $\mathrm{MgCl}_{2}, 0.42 \mathrm{mM} \mathrm{NaH} \mathrm{PO}_{4}, 11.9 \mathrm{mM} \mathrm{NaHCO}$, and $11.1 \mathrm{mM}$ glucose. After stabilization with $95 \% \mathrm{O}_{2} / 5 \% \mathrm{CO}_{2}, \mathrm{pH}$ was 7.0 . The preparations were indirectly stimulated with supramaximal stimuli ( $4 \mathrm{x}$ threshold, $0.06 \mathrm{~Hz}, 0.2 \mathrm{~ms}$ ) delivered from a stimulator (model ESF-15 $5^{\circ}$, Bonter, Brazil) to the nerve through bipolar electrodes. Isometric twitch tension was recorded with a force displacement transducer (cat. 7003, Ugo Basile, Italy) coupled to a Gemini two-channel physiographic recorder (cat. 7070, Ugo Basile) via a basic preamplifier (cat. 7080, Ugo Basile, Italy).

Organ preparations $(n=6)$ were allowed to stabilize for at least 20 minutes before the addition of the following: Tyrode solution (control); 0.05, $0.1,1$ and $2 \mathrm{mg} / \mathrm{mL} \mathrm{Cg}$ (i.e. 0.25, 0.5, 5 and $10 \mathrm{mg}$
Cg, respectively); $60 \mu \mathrm{g} / \mathrm{mL}$ Bjssu venom (i.e., 300 $\mathrm{mg}$ or $0.3 \mathrm{mg}$ ); and $60 \mu \mathrm{g} / \mathrm{mL}$ Bjssu venom +0.05 , 0.1 and $1 \mathrm{mg} / \mathrm{mL} \mathrm{Cg}$. Two other experiments were carried out: organ preparations preincubated with $0.1 \mathrm{mg} / \mathrm{mL} \mathrm{Cg}$ extract during 30 minutes, followed by addition of $60 \mu \mathrm{g} / \mathrm{mL}$ crude Bjssu venom; and organ preparations subjected to 60 $\mu \mathrm{g} / \mathrm{mL}$ crude Bjssu venom during 15 minutes, followed by addition of $1 \mathrm{mg} / \mathrm{mL}$ Cg extract.

\section{Statistical analysis}

Each pharmacological protocol was repeated at least five times. Results were expressed as the mean \pm standard deviation (SD). ANOVA and Tukey's (post hoc) tests were used for data comparison. The significance level was set at 5\%.

\section{RESULTS AND DISCUSSION}

The chemical composition of plant extracts is very complex and variable as it depends on the climate and/or the soil composition (36). Thus, physicochemical control is indispensable for phytotherapics. Drug discovery techniques applied to the standardization of herbal medicines have revealed numerous analytical marker compounds. In the present study, quality control tests such as pharmacognostic methods, characteristic fingerprint chromatograms, defined amounts of marker substances and physicochemical characteristics were used for the extract standardization (37).

According to Brazilian Pharmacopeia (31), the usual values for extract ashes are up to $2 \%$ and for humidity, $14 \%$. The results (mean \pm SD, in grams/100 g) obtained in the ash and humidity tests for Cg were $3.67 \pm 0.48$ and $11.47 \pm 1.02$, respectively. The high ash content found in $\mathrm{Cg}$ powder indicates the presence of inorganic compounds due to the soil composition, although no correlation between elemental composition of medicinal plants and their curative properties have been established (38). The humidity level found for $\mathrm{Cg}$ powder confirms that no enzymatic reaction occurred during sample collection.

Preliminary phytochemical analysis of the plant crude extract, using thin layer chromatography (Figure 1), showed the presence of flavonoids (orange coloration) and other phenolic constituents (blue coloration), revealing a similar profile with Casearia sylvestris Sw., a well known Casearia species. The Rf values obtained 
using solvent system A were $0.105,0.158,0.211$, $0.303,0.338,0.434,0.487,0.526,0.632,0.737$, 0.829 and 0.882 for $C$. sylvestris (Cs); $0.110,0.178$, $0.411,0.480,0.548,0.616,0.658,0.712,0.781$ and 0.959 for C. gossypiosperma (Cg); and 1.0, 0.987 and 0.321 for the phytochemical standards apigenin, quercetin and rutin, respectively. The presence of substances with the same $\mathrm{Rf}$ for both C. gossypiosperma and C. sylvestris suggests common metabolites.

The $\mathrm{Rf}$ values obtained using solvent system $\mathrm{B}$ were $0.307,0.387,0.493,0.547$ and 0.880 for Cs; $0.181,0.403$ and 0.458 for Cg; and 0.663 and 0.400 for apigenin and quercetin, respectively, whereas rutin was not displaced by the solvent. In this solvent system, Cg spots are suggestive of rutin, quercetin and another flavonoid not identified (orange coloration).

Orange and blue compounds in the plants, visualized by TLC, are suggestive of flavonoids and polyphenol compounds and here were quantitatively confirmed as $0.624 \mathrm{~g} \%$ (quercetin calibration curve $\mathrm{Y}=0.0632 \mathrm{X}+0.0035, \mathrm{r}=$ 0.998 ) and $4.63 \mathrm{~g} \%$ (pyrogallol calibration curve $\mathrm{Y}=0.1693 \mathrm{X}-0.0004, \mathrm{r}=0.999)$ for $\mathrm{Cg}(32)$. The latter has very similar flavonoid content but
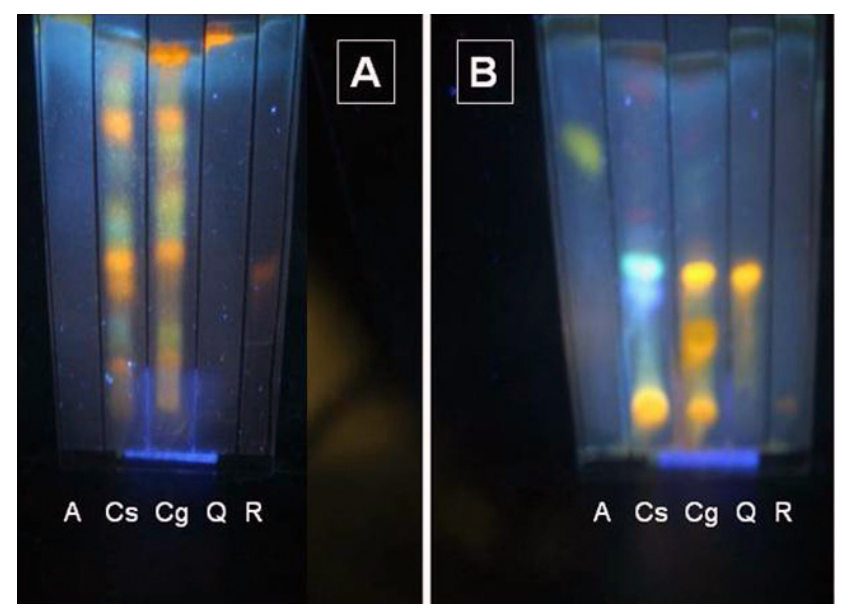

Figure 1. Comparative thin layer chromatography between Casearia sylvestris (Cs) and Casearia gossypiosperma $(\mathrm{Cg})$. Chromatographical profile of extracts and phytochemical standards under solvents A (ether acetate:formic acid:water, 9:1:1, $\mathrm{v} / \mathrm{v}$ ) and $\mathrm{B}$ (acetone:chloroform:formic acid, 10:75:8, $\mathrm{v} / \mathrm{v})$. Note the similarity of compounds between (A) Casearia spp. and the presence of rutin and quercetin and another unidentified orange compound in (B) C. gossypiosperma. A: apigenin; Q: quercetin; R: rutin. twice more polyphenol concentration compared to C. sylvestris ( $0.640 \mathrm{~g} \%$ and $2.22 \mathrm{~g} \%$ for flavonoids and polyphenols, respectively); these parameters were measured by the methodology described elsewhere (39). This variation in plant compounds can change medicinal properties (40). Parameters such as ash production, humidity, flavonoids and phenols are important for phytochemical characterization and maintenance of a physicochemical standard of plant extracts. In the present study, the plant assays showed reproducibility, which could indicate that the extracts had good standardization.

The major constituents (flavonoids and polyphenols) of Cg hydroalcoholic extracts were identified by TLC and spectrophotometrically quantified, and their capability to inhibit neuromuscular activities of bothropic venom was demonstrated in vitro. Crude Bjssu venom induces neurotoxicity in vitro and causes muscle necrosis in vivo, resulting in irreversible tissue loss and limb amputation in severe accidents $(29,30)$. Muscle necrosis is usually attributed to bothropstoxin-I, which is a myotoxic Lys49 $\mathrm{PLA}_{2}$ homologue and the main toxic component of Bjssu venom (41). The myotoxic components of snake venoms can reduce the initiation of muscle contractures, muscle response after direct stimulation or elevated potassium exposure (42). In this work, the addition of Bjssu venom $(60 \mu \mathrm{g} /$ $\mathrm{mL}$ or $0.3 \mathrm{mg}, \mathrm{n}=6$ ) alone to the bath produced total muscle paralysis starting at $26 \pm 2$ minutes until the end of the experiment.

Figure 2 shows the bioassays on the muscle activity of mouse phrenic nerve-diaphragm preparations using $0.05,0.1,1$ and $2 \mathrm{mg} / \mathrm{mL}$ (or $0.25,0.5,5$ and $10 \mathrm{mg}$, respectively) $\mathrm{Cg}$ hydroalcoholic extract over 120 minutes. Except $0.05 \mathrm{mg} / \mathrm{mL}$, all other $\mathrm{Cg}$ extract concentrations significantly decreased the muscle activity. However, in all assays, a total recovery of the muscle activity was verified after total removal of extracts by washing the preparations with fresh Tyrode solution. The concentrations of $0.05,0.1$ and $1 \mathrm{mg} / \mathrm{mL}$ Cg extract were assayed with crude Bjssu venom.

Figure 3 shows the neutralization of Bjssu venom by $\mathrm{Cg}$ extract mixed with venom in the bath kept at $37^{\circ} \mathrm{C}$ for $120 \mathrm{~min}$. Curiously, after decreasing muscle activity, $0.1 \mathrm{mg} / \mathrm{mL} \mathrm{Cg} \mathrm{extract}$ significantly $(\mathrm{p}<0.05)$ reduced muscle paralysis by $87.6 \pm 1.8 \%(n=6)$. The protective action 


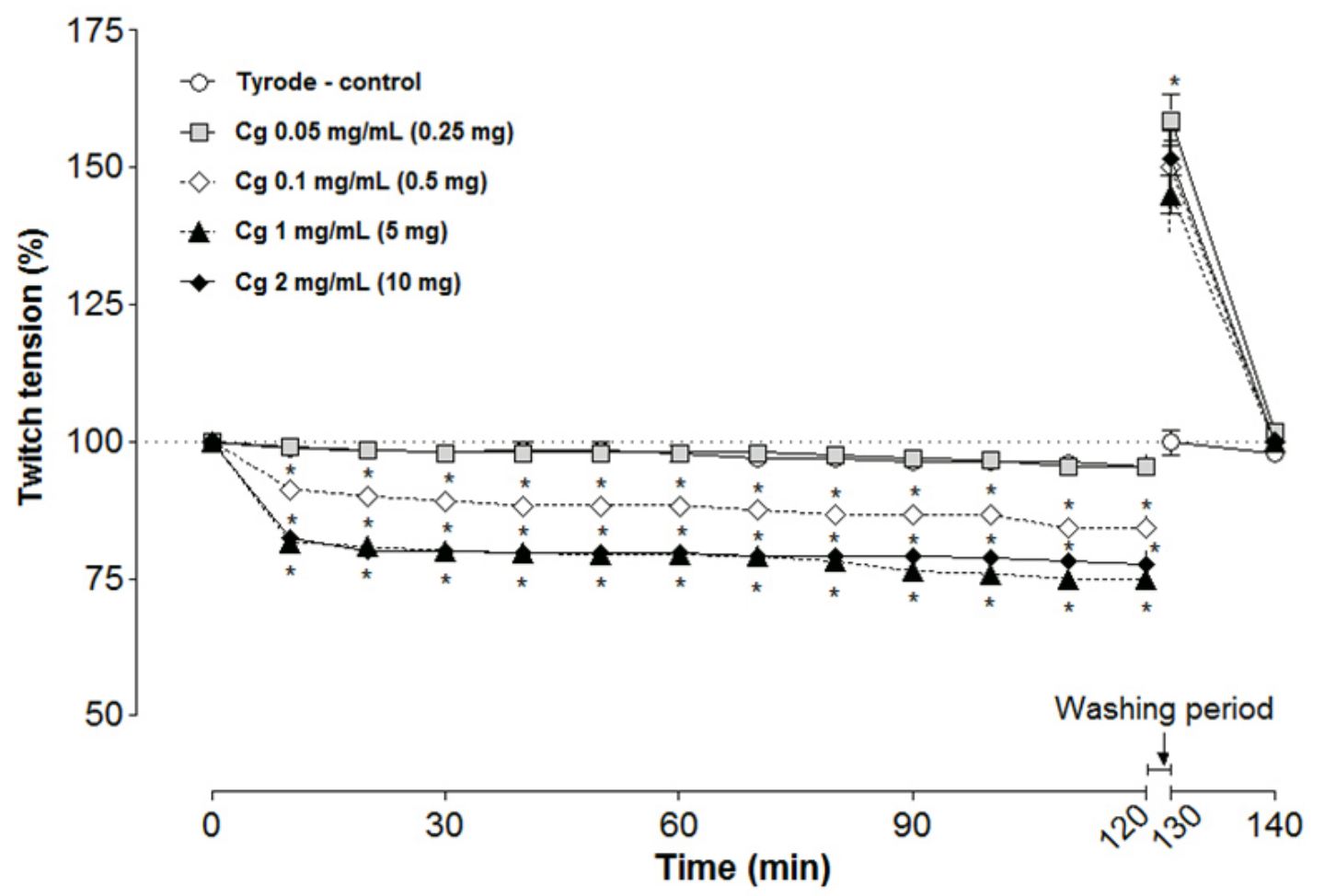

Figure 2. Twitch tension of mouse isolated phrenic nerve-diaphragm preparations under indirect stimuli, in percentage (each point represents the mean $\pm \mathrm{SEM}, \mathrm{n}=6$ ). Action of $\mathrm{Cg}$ hydroalcoholic extracts at concentrations of $0.05,0.1,1$ and $2 \mathrm{mg} / \mathrm{mL}$ (or $0.25,0.5,5$ and $10 \mathrm{mg}$, respectively). All extract concentration, except the first one, significantly differed from that of Tyrode solution (control) during 120 minutes $\left({ }^{*} \mathrm{p}<0.05\right)$.

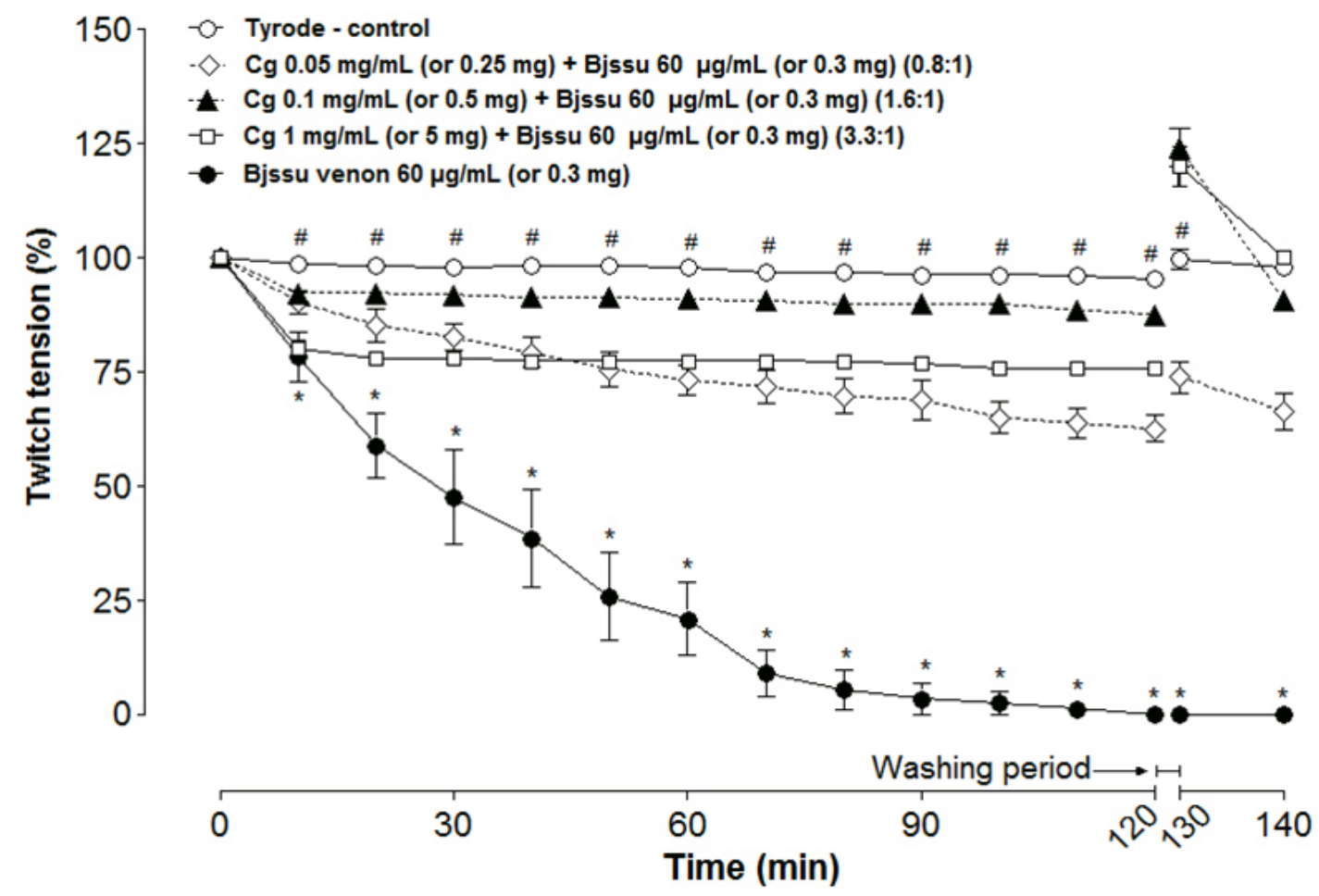

Figure 3. Twitch tension of mouse isolated phrenic nerve-diaphragm preparations under indirect stimuli, in percentage (each point represents the mean $\pm S E M, n=6$ ). Neuromuscular blockade by Bjssu venom (60 $\mu \mathrm{g} / \mathrm{mL}$ or $300 \mathrm{mg}$ or $0.3 \mathrm{mg}$ ) and assays of neutralization by Cg hydroalcoholic extracts $(0.05,0.1 \mathrm{and} 1 \mathrm{mg} /$ $\mathrm{mL}$ or $0.25,0.5$ and $5 \mathrm{mg}$, respectively), compared to Tyrode solution (control) during 120 minutes. ${ }^{*} \mathrm{p}<0.05$ compared to Tyrode control for all periods (except 0). \# $p<0.05$ compared to Tyrode control and Bjssu venom. 


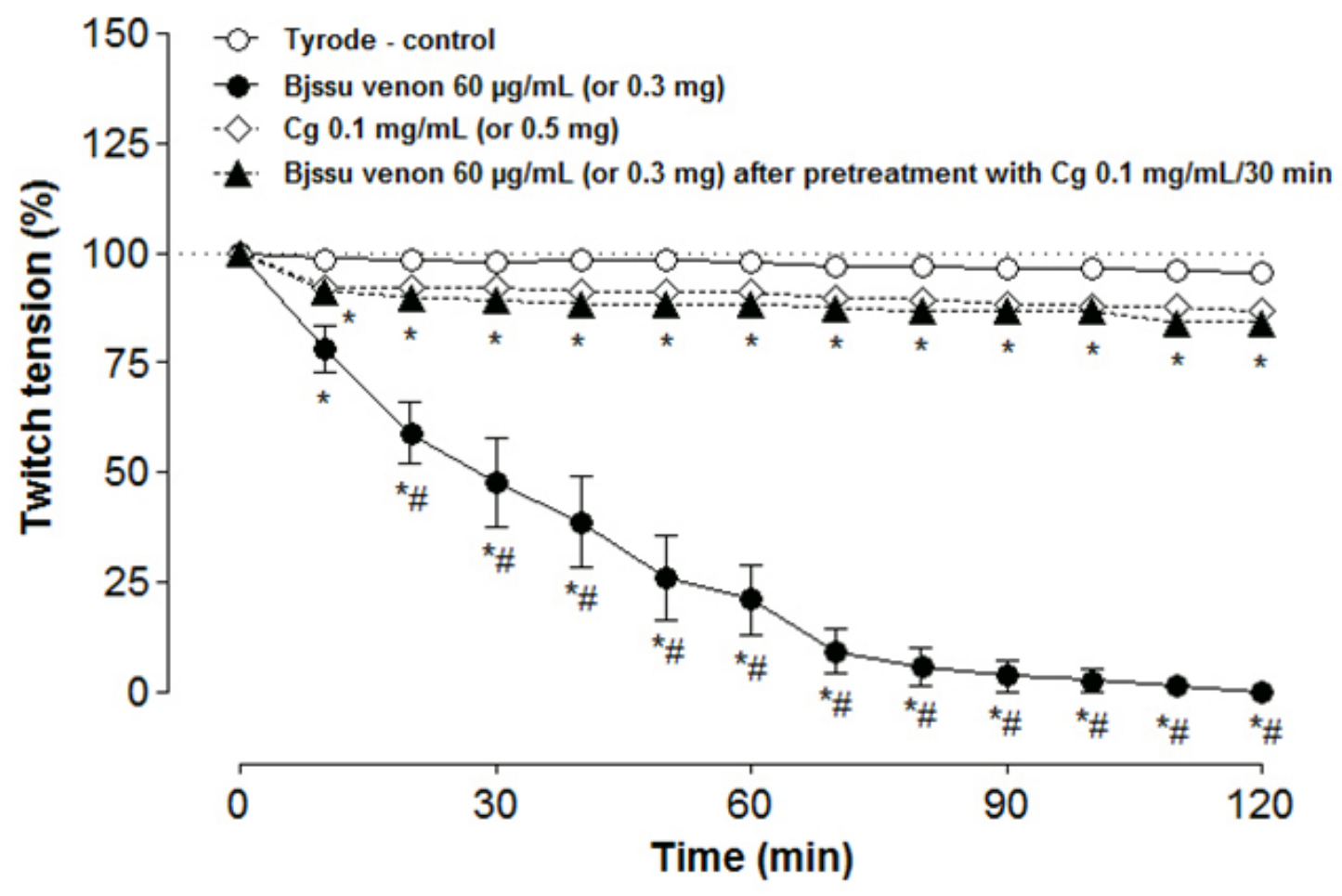

Figure 4. Twitch tension of mouse isolated phrenic nerve-diaphragm preparations under indirect stimuli, in percentage (each point represents the mean $\pm S E M, n=6$ ). Pretreatment of preparations with $0.1 \mathrm{mg} /$ $\mathrm{mL}$ (or $0.5 \mathrm{mg}$ ) Cg hydroalcoholic extract for 30 minutes, followed by $60 \mu \mathrm{g} / \mathrm{mL}$ (or $300 \mathrm{mg}$ or $0.3 \mathrm{mg}$ ) Bjssu venom addition during 120 minutes. ${ }^{*} \mathrm{p}<0.05$ compared to Tyrode control for all periods (except 0 ). \# $\mathrm{p}<$ 0.05 compared to $\mathrm{Cg}$ extract alone or to pretreatment with Cg extract.

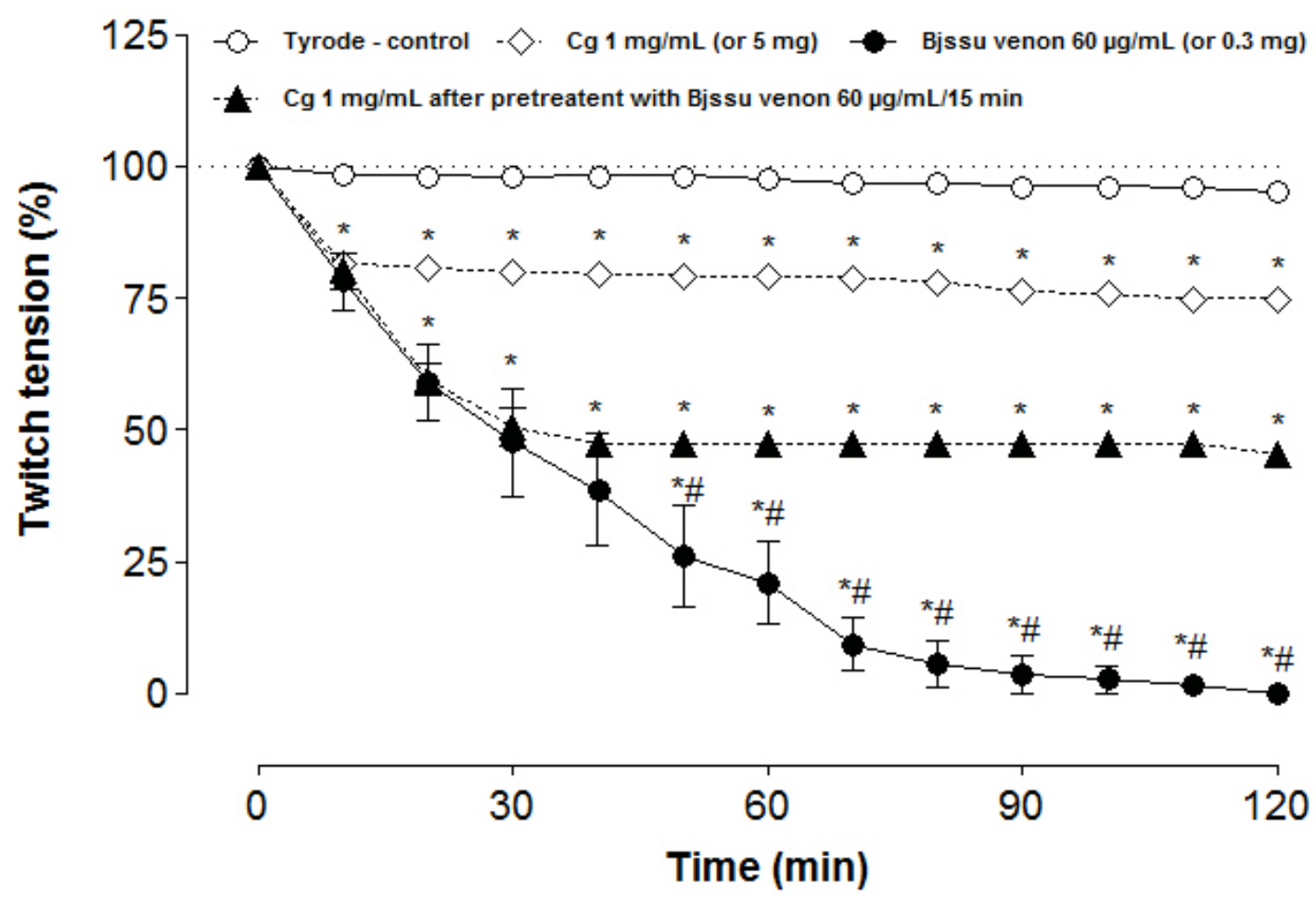

Figure 5. Twitch tension of mouse isolated phrenic nerve-diaphragm preparations under indirect stimuli, in percentage (each point represents the mean $\pm S E M, n=6$ ). Post-treatment of preparations with $1 \mathrm{mg} /$ $\mathrm{mL}$ (or $5 \mathrm{mg}$ ) Cg hydroalcoholic extract after 15 minutes, followed by $60 \mu \mathrm{g} / \mathrm{mL}$ (or $300 \mathrm{mg}$ or $0.3 \mathrm{mg}$ ) Bjssu venom addition. ${ }^{*} p<0.05$ compared to Tyrode control for all periods (except 0 ). $\# p<0.05$ compared to treatment with Bjssu during 15 minutes, followed by $\mathrm{Cg}$ extract addition. 
against crude venom was confirmed by a total recovery after washing $(\mathrm{W})$.

Using the same experimental model, two organ preparations were observed, pretreatment: preincubation with $\mathrm{Cg}$ extract followed by addition of crude Bjssu venom (Figure $4, \mathrm{n}=6$ ); and post-treatment: addition of $\mathrm{Cg}$ extract after 15 minutes of Bjssu venom exposure (Figure 5, $\mathrm{n}=6$ ). Preincubation with $\mathrm{Cg}$ extract protected the muscle against the blockade induced by Bjssu venom, similarly to the results shown in Figure 3. Post-treatment with $0.1 \mathrm{mg} / \mathrm{mL} \mathrm{Cg}$ extract did not change the blockade profile (not shown), but 1 $\mathrm{mg} / \mathrm{mL}$ Cg extract partially and significantly $(\mathrm{p}<$ 0.05 ) protected against the total blockade induced by Bjssu venom. This result could indicate that $1 \mathrm{mg} / \mathrm{mL} \mathrm{Cg}$ extract could prevent the venom activity propagation. Since only higher $\mathrm{Cg}$ concentrations showed pharmacological effect, the bioactive compounds could be concentrated in the extract, which is interesting for a future $C$. gossypiosperma bio-prospection.

The inhibition of neurotoxic and myotoxic activities of snake venoms in similar experimental models was also previously observed for crude extracts of Tabernaemontana catharinensis, Casearia sylvestris, Pentaclethra macroloba, Baccharis trimera and Mandevilla velutina (27, 39, 43-47).

Our experience with C. sylvestris $(27,39)$ using the same experimental model and all attempts to identify the bioactive compounds (mainly rutin) showed that this plant protected the muscle against the toxic effects of Bjssu venom due to phytocomplex formation. Different molecules in the plant constitution inhibit Bjssu venom activity in different ways, for example, coumarin from Mikania laevigata and tannin from Plathymenia reticulata. In commercial phytochemical preparations, these molecules (coumarin and tannic acid) confirmed the capability to revert Bjssu venom-induced muscle blockade by pharmacological (M. laevigata) or protein precipitation (P. reticulata) (48). We also observed that the capability to protect against the neuromuscular blockade induced by Bjssu venom does mean protection against the paralysis caused by Crotalus durissus terrificus venom (data not published), which indicates that the mechanism of action of the venoms must be considered and the plant and venom mixing is not enough to neutralize the toxic effects.
In the present study, the neuromuscular blockade induced by Bjssu venom was inhibited by $\mathrm{Cg}$ hydroalcoholic extract, suggesting the presence of compounds with the ability to reduce neurotoxicity and effectively inhibit the myotoxic action of the venom. Based on the similarity of the constituents found in C. gossypiosperma to those seen in C. sylvestris, we suggest the same mechanism of action for both, i.e., phytocomplex formation between venom and antioxidants (flavonoids and polyphenols). This is the first attempt to show the antivenom activity of $C$. gossypiosperma and prove its ethnobotanical use. Further studies are needed to identify the bioactive compound(s) responsible for the antineurotoxic and antimyotoxic effects of $\mathrm{Cg}$.

\section{ACKNOWLEDGEMENTS}

The authors thank Marcos Magoiti Minami for collecting C. gossypiosperma Briquet; CEP/ UNIVAP for ethical assistance; PIBIC/CNPq and PROBIC/Uniso for fellowships; and The State of São Paulo Research Foundation (FAPESP) for financial support.

\section{COPYRIGHT \\ (C) CEVAP 2010}

\section{SUBMISSION STATUS}

Received: February 19, 2010.

Accepted: April 7, 2010.

Abstract published online: April 12, 2010.

Full paper published online: August 31, 2010.

\section{CONFLICTS OF INTEREST}

There is no conflict.

\section{FINANCIAL SOURCE \\ PIBIC/CNPq, PROBIC/Uniso and FAPESP.}

\section{ETHICS COMMITTEE APPROVAL}

The present study was approved by the Research Ethics Committee of Vale do Paraíba University, UNIVAP, São José dos Campos, SP, Brazil (protocol number A009/2006 CEP). In addition, all animal experiments were performed according to the guidelines of the Brazilian Society of Laboratory Animal Science (SBCAL/CEUA).

\section{CORRESPONDENCE TO}

YOKO OSHIMA-FRANCO, Universidade de Sorocaba, UNISO, Cidade Universitária, Rodovia 
Raposo Tavares, km 92,5, Sorocaba, SP, 18.023000, Brasil. Phone: +55 152101 7041. Fax: +55 152101 7112. Email: yoko.franco@prof.uniso.br.

\section{REFERENCES}

1. Klein RM, Sleumer HO. Flacourtiáceas. In: Reitz $\mathrm{R}$, editor. Flora Ilustrada Catarinense. Fascículo Flac. Itajaí: Raulino Reitz; 1984. p.1-96.

2. Beutler JA, McCall KL, Herbert K, Herald DL, Pettit GR, Johnson T, et al. Novel cytotoxic diterpenes from Casearia arborea. J Nat Prod. 2000;63(5):657-61.

3. Mosaddik MA, Banbury L, Forster P, Booth R, Markham J, Leach D, et al. Screening of some Australian Flacourtiaceae species for in vitro antioxidant, cytotoxic and antimicrobial activity. Phytomedicine 2004;11(5):461-6.

4. Kanokmedhakul S, Kanokmedhakul K, Buayairaksa M. Cytotoxic clerodane diterpenoids from fruits of Casearia grewiifolia. J Nat Prod. 2007;70(7):11226.

5. Sai Prakash CV, Hoch JM, Kingston DG. Structure and stereochemistry of new cytotoxic clerodane diterpenoids from the bark of Casearia lucida from the Madagascar rainforest. J Nat Prod. 2002;65(2):100-7.

6. Ashik M, Flowers MA, Karagianis G, Waterman PG. New phenolic glycosides from the stems and leaves of Casearia multinervosa. Nat Prod Res. 2006;20(6):641-7.

7. Williams RB, Norris A, Miller JS, Birkinshaw C, Ratovoson F, Andriantsiferana R, et al. Cytotoxic clerodane diterpenoids and their hydrolysis products from Casearia nigrescens from the rainforest of Madagascar. J Nat Prod. 2007;70(2):206-69.

8. Vieira GM Jr, Gonçalves $\mathrm{T}$ de $\mathrm{O}$, Regasini LO, Ferreira PM, Pessoa C do O, Costa Lotufo LV, et al. Cytotoxic clerodane diterpenoids from Casearia obliqua. J Nat Prod. 2009;72(10):184750.

9. Agripino DG, Lima MEL, Silva MR, Meda CI, Bolzani VS, Cordeiro I, et al. Screening of Brazilian plants for antimicrobial and DNA-damaging activities. I. Atlantic rain forest. Ecological station Juréia-Itatins. Biota Neotropica 2004;4(2):1-15.

10. Chandramohan G, Ignacimuthu S, Pugalendi KV. A novel compound from Casearia esculenta (Roxb.) root and its effect on carbohydrate metabolism in streptozotocin-diabetic rats. Eur J Pharmacol. 2008;590(1-3):437-43.

11. Hunter MS, Corley DG, Carron CP, Rowold E, Kilpatrick BF, Durley RC. Four new clerodane diterpenes from the leaves of Casearia guianensis which inhibit the interaction of leukocyte function antigen 1 with intercellular adhesion molecule 1. J Nat Prod. 1997;60(9):894-9.

12. Weniger B, Haag-Berrurier M, Anton R. Plants of Haiti used as antifertility agents. J Ethnopharmacol. 1982;6(1):67-84.

13. Izidoro LF, Rodrigues VM, Rodrigues RS, Ferro EV, Hamaguchi A, Giglio JR, et al. Neutralization of some hematological and hemostatic alterations induced by neuwiedase, a metalloproteinase isolated from Bothrops neuwiedi pauloensis snake venom, by the aqueous extract from Casearia mariquitensis (Flacourtiaceae). Biochimie. 2003;85(7):669-75.

14. Chen CY, Cheng YB, Chen SY, Chien CT, Kuo $\mathrm{YH}$, Guh JH, et al. New bioactive clerodane diterpenoids from the roots of Casearia membranacea. Chem Biodivers. 2008;5(1):162-7.

15. Awasthy KS, Chaurasia OP, Sinha SP, Khan PK. Differential genotoxicity of the crude leaf extract of a medicinal plant, Casearia tomentosa. Biomed Environ Sci. 2000; 13(1):12-8.

16. Chai XY, Li FF, Bai CC, Xu ZR, Shi HM, Tu PF. Three new acylated glycosides from the stems of Casearia velutina and their protective effect against $\mathrm{H} 2 \mathrm{O} 2$-induced impairment in $\mathrm{PC} 12$ cells. Planta Med. 2010;76(1):91-3.

17. Itokawa $\mathrm{H}$, Totsuka $\mathrm{N}$, Takeya $\mathrm{K}$, Watanabe $\mathrm{K}$, Obata E. Antitumor principles from Casearia sylvestris Sw. (Flacourtiaceae), structure elucidation of new clerodane diterpenes by 2-D NMR spectroscopy. Chem Pharm Bull (Tokyo). 1988;36(4):1585-8.

18. Basile AC, Sertié JA, Panizza S, Oshiro TT, Azzolini CA. Pharmacological assay of Casearia sylvestris. I: Preventive anti-ulcer activity and toxicity of the leaf crude extract. J Ethnopharmacol. 1990;30(2):185-97.

19. Ruppelt BM, Pereira EF, Gonçalves LC, Pereira NA. Pharmacological screening of plants recommended by folk medicine as anti-snake venom - I. Analgesic and anti-inflammatory activities. Mem Inst Oswaldo Cruz. 1991;86 Suppl 2:203-5.

20. Morita H, Nakayama M, Kojima H, Takeya K, Itokawa H, Schenkel EP, et al. Structures and cytotoxic activity relationship of casearins, new clerodane diterpenes from Casearia sylvestris Sw. Chem Pharm Bull (Tokyo). 1991;39(3):693-7.

21. Bolzani V da S, Young MC, Furlan M, Cavalheiro $\mathrm{AJ}$, Araújo AR, Silva $\mathrm{DH}$, et al. Search for antifungal and anticancer compounds from native plant species of Cerrado and Atlantic Forest. An Acad Bras Cienc. 1999;71(2):181-7.

22. Borges MH, Soares AM, Rodrigues VM, AndriãoEscarso SH, Diniz H, Hamaguchi A, et al. Effects of aqueous extract of Casearia sylvestris 
(Flacourtiaceae) on actions of snake and bee venoms and on activity of phospholipases A2. Comp Biochem Physiol B Biochem Mol Biol. 2000;127(1):21-30.

23. Maistro EL, Carvalho JC, Mantovani MS. Evaluation of the genotoxic potential of the Casearia sylvestris extract on HTC and V79 cells by the comet assay. Toxicol In Vitro. 2004;18(3):337-42.

24. Espindola LS, Vasconcelos Júnior JR, de Mesquita ML, Marquié P, de Paula JE, Mambu L, et al. Trypanocidal activity of a new diterpene from Casearia sylvestris var. lingua. Planta Med. 2004;70(11):1093-5.

25. da Silva AC, Balz D, de Souza JB, Morsch VM, Corrêa MC, Zanetti GD, et al. Inhibition of NTPDase, 5'-nucleotidase, $\mathrm{Na}+\mathrm{K}+$-ATPase and acetylcholinesterase activities by subchronic treatment with Casearia sylvestris. Phytomedicine. 2006; 13(7):509-14.

26. Schoenfelder T, Pich CT, Geremias R, Avila S, Daminelli EN, Pedrosa RC, et al. Antihyperlipidemic effect of Casearia sylvestris methanolic extract. Fitoterapia. 2008; 79(6):465-7.

27. Cintra-Francischinelli M, Silva MG, AndréoFilho N, Gerenutti M, Cintra AC, Giglio JR, et al. Antibothropic action of Casearia sylvestris Sw (Flacourtiaceae) extracts. Phytother Res. 2008;22(6):784-90.

28. Rodrigues E. Plants and animals utilized as medicines in the Jaú National Park (JNP), Brazilian Amazon. Phytother Res. 2006;20(5):378-91.

29. Ministério da Saúde do Brasil. Manual de diagnóstico e tratamento de acidentes por animais peçonhentos. 2nd ed. Brasília: Fundação Nacional de Saúde; 2001. $120 \mathrm{p}$.

30. Rodrigues-Simioni L, Borgese N, Ceccarelli B. The effects of Bothrops jararacussu venom and its components on frog nerve-muscle preparation. Neuroscience. 1983;10(2):475-89.

31. Farmacopéia brasileira. 4th ed. São Paulo: Atheneu; 1988.

32. Harbone JB. Phytochemical methods: a guide to modern techniques of plants analysis. London: Chapman \& Hall; 1998. 302 p.

33. Mori ALPM. Própolis - identificação de flavonóides e ácidos aromáticos em tintura. Estimativa de FPS de extrato mole em base cosmética [dissertation]. São Paulo: Faculdade de Ciências Farmacêuticas; 1997. $114 \mathrm{p}$.

34. Portuguese pharmacopoeia. 7th ed. Lisboa: Infarmed; $2002.2792 \mathrm{p}$.

35. Bülbring E. Observations on the isolated phrenic nerve diaphragm preparation of the rat. $\mathrm{Br} \mathrm{J}$ Pharmacol Chemother. 1946;1(1):38-61.

36. Monteiro JM, Albuquerque UP, Lins Neto EMF, Araújo EL, Albuquerque MM, Amorim ELC.
The effects of seasonal climate changes in the caatinga on tannin levels in Myracrodruon urundeuva (Engl.) Fr. All. and Anadenanthera colubrine (Vell.) Brenan. Rev Bras Farmacogn. 2006;16(3):338-44.

37. Kroll U, Cordes C. Pharmaceutical prerequisites for a multi-target therapy. Phytomedicine. 2006;13 Suppl 5:12-9.

38. Yamashita CI, Saiki M, Vasconcellos MB, Sertié JA. Characterization of trace elements in Casearia medicinal plant by neutron activation analysis. Appl Radiat Isot. 2005;63(5-6):841-6.

39. Oshima-Franco Y, Alves CMV, Andréo-Filho N, Gerenutti M, Cintra ACO, Leite GB, et al. Neutralization of the neuromuscular activity of bothropstoxin-I, a myotoxin from Bothrops jararacussu snake venom, by a hydroalcoholic extract of Casearia sylvestris Sw. (Guaçatonga). J Venom Anim Toxins incl Trop Dis. 2005;11(4):465-78.

40. Santos SC, Costa WF, Batista F, Santos LR, Ferri $\mathrm{PH}$, Ferreira HD, et al. Seasonal variation in the content of tannins in barks of barbatimão species. Rev Bras Pharmacogn. 2006;16(4):552-6.

41. Oshima-Franco Y, Leite GB, Belo CA, Hyslop $\mathrm{S}$, Prado-Franceschi J, Cintra AC, et al. The presynaptic activity of bothropstoxin-I, a myotoxin from Bothropsjararacussu snake venom. Basic Clin Pharmacol Toxicol. 2004;95(4):175-82.

42. Geh SL, Rowan EG, Harvey AL. Neuromuscular effects of four phospholipases A2 from the venom of Pseudechis australis, the Australian king brown snake. Toxicon. 1992;30(9):1051-7.

43. Batina Mde F, Cintra AC, Veronese EL, Lavrador MA, Giglio JR, Pereira PS, et al. Inhibition of the lethal and myotoxic activities of Crotalus durissus terrificus venom by Tabernaemontana catharinensis: identification of one of the active components. Planta Med. 2000;66(5):424-8.

44. Cavalcante WL, Campos TO, Dal Pai-Silva M, Pereira PS, Oliveira CZ, Soares AM, et al. Neutralization of snake venom phospholipase A2 toxins by aqueous extract of Casearia sylvestris (Flacourtiaceae) in mouse neuromuscular preparation. J Ethnopharmacol. 2007;112(3):4907.

45. da Silva JO, Coppede JS, Fernandes VC, Sant'Ana CD, Ticli FK, Mazzi MV, et al. Antihemorrhagic, antinucleolytic and other antiophidian properties of the aqueous extract from Pentaclethra macroloba. J Ethnopharmacol. 2005;100(12):145-52.

46. Januário AH, Santos SL, Marcussi S, Mazzi MV, Pietro RC, Sato DN, et al. Neo-clerodane diterpenoid, a new metalloprotease snake venom inhibitor from Baccharis trimera (Asteraceae): 
anti-proteolytic and anti-hemorrhagic properties. Chem Biol Interact. 2004;150(3):243-51.

47. Biondo R, Pereira AM, Marcussi S, Pereira PS, França SC, Soares AM. Inhibition of enzymatic and pharmacological activities of some snake venoms and toxins by Mandevilla velutina (Apocynaceae) aqueous extract. Biochimie. 2003;85(10):1017-25.
48. Melo RS, Farrapo NM, Rocha Junior DS, Silva MG, Cogo JC, Dal Belo CA, et al. Antiophidian mechanisms of medicinal plants. In: Keller RB, editor. Flavonoids: biosynthesis, biological effects and dietary sources. New York: Nova Science Publishers; 2009. p. 249-62. 